УДК 351.712

B. В. Чурилов, здобувач, Начіональний університет иливільного захисту Украӥни, м. Харків ORCID ID: 0000-0002-9483-430X

DOI: $10.32702 / 2306-6814.2021 .20 .130$

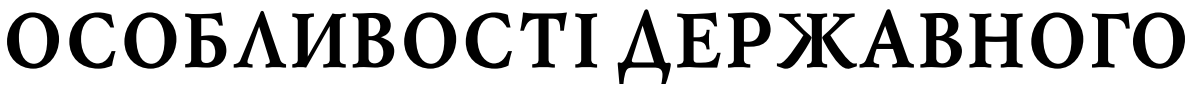

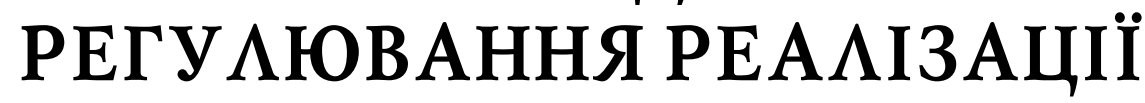

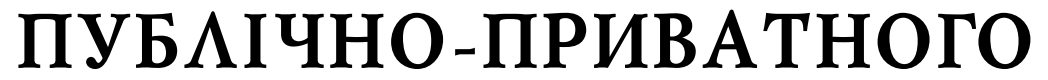 ПАРТНЕРСТВА У БУАІВНИЦТВІ
}

\author{
V. Churylov, \\ Candidate for a degree, National University of Civil Defense of Ukraine, Kharkiv
}

\section{FEATURES OF STATE REGULATION OF PUBLIC-PRIVATE PARTNERSHIP IN CONSTRUCTION}

Зазначено, що особливістю сучасного етапу функціонування державного сектора в економічно розвинених країнах є суттєва трансформація відносин власності та управління в галузях виробничої інфраструктури, що мають ознаки природних монополій та включають виробничу, транспортнута соціальну інфраструктуру. До останнього часу інфраструктурні об'єкти, на частку яких припадає значна частина інвестицій і зайнятого населення в розвинених країнах, залишалися, як правило, об'єктами державної власності і прямого державного фінансування. В умовах дефіциту бюджетів всіх рівнів пріоритет віддається принципам управління, орієнтованим на скорочення частки державних витрат в інфраструктурних об'єктах та сфері надання громадських послуг. Ефективною формою такого співробітництва стає інститут партнерства держави і приватного сектора, який прийнято називати терміном "публічне-приватне партнерство"(ППП). Визначено, що найбільш поширеними як у світовій, так і в українській практиціє такі форми ППП, як операторський контракт, оренда, концесія, контракт життєвого циклу. За оцінками експертів, три види концесійних угод сьогодні є найбільш поширеними в інфраструктурних галузях світової економіки: на діючі об'єкти виробничої, транспортної та соціальної інфраструктури; на створення нових об'єктів або модернізацію морально чи фізично застарілих; на передачу об'єктів державної власності в оперативне управління приватним компаніям.

It is noted that the feature of the current stage of functioning of the public sector in economically developed countries is a significant transformation of ownership and management in the areas of industrial infrastructure, which have the characteristics of natural monopolies and include industrial, transport and social infrastructure. Until recently, infrastructure facilities, which account for a significant share of investment and employment in developed countries, remained, as a rule, objects of state ownership and direct state funding. Given the deficit of budgets at all levels, priority is given to management principles aimed at reducing the share of public spending in infrastructure and public services. An effective form of such cooperation is the institution of public-private partnership, which is commonly referred to as "public-private partnership" (PPP). It is determined that the most common in both world and Ukrainian practice are such forms of PPP as operator contract, lease, concession, life cycle contract. According to experts, three types of concession agreements today are the most common in the infrastructure sectors of the world economy: the existing facilities of industrial, transport and social infrastructure; to create new facilities or upgrade morally or physically obsolete; 
for the transfer of state property to the operational management of private companies. Within the above types, different combinations of rights and transactions of the parties to the agreement are possible. Such projects are called life-cycle contracts, which, along with concessions, are widely used in transport infrastructure, and in particular in the road sector. In such projects, the state builds relations with private business by: developing a strategy and basic principles for regulating the relations of private business with the public and public authorities; formation of institutional and legislative environment that creates favorable conditions for the implementation of PPP - projects; effective organization and management of the project on the basis of adequate forms, methods and mechanisms of optimization of activity for all participants of partnership.

КлючоВі слова: держаВне регулюВання, публічно-приВатне партнерство, будіВництво, фрункціонуВання держаВного сектора, Виробнича інфраструктура, держаВне фрінансуВання, концесійні угоди, принципи регулюВання Відносин.

Key words: state regulation, public-private partnership, construction, functioning of the public sector, production infrastructure, state financing, concession agreements, principles of regulation of relations.

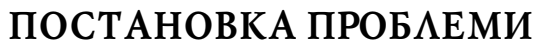

Особливістю сучасного етапу функціонування державного сектора в економічно розвинених країнах $€$ суттєва трансформація відносин власності та управління в галузях виробничої інфраструктури, що мають ознаки природних монополій та включають виробничу, транспортну та соціальну інфраструктуру. До останнього часу інфраструктурні об'єкти, на частку яких припадає значна частина інвестицій і зайнятого населення в розвинених країнах, залишалися, як правило, об'єктами державної власності і прямого державного фрінансування. В умовах десріциту бюджетів всіх рівнів пріоритет віддається принципам управління, орієнтованим на скорочення частки державних витрат в інфраструктурних об'єктах та сорері надання громадських послуг. Ефективною формою такого співробітництва стає інститут партнерства держави і приватного сектора, який прийнято називати терміном "публічне-приватне партнерство "(ППП).

У 1920-ті роки ця ідея отримала теоретичне і методичне обгрунтування в працях радянських економістів, створювали основи нової економічної політики держави. Акцент в таких проєктах, з урахуванням складного стану економіки після громадянської війни, був орієнтований на партнерство з іноземними інвесторами, тим більше що у країни після громадянської війни не було сучасних технологій і трудових ресурсів високої кваліфрікації для вирішення першочергових завдань, передусім в оборонній промисловості.

\section{АНА $\Lambda$ I3 ОСТАНHIX АОС $\Lambda$ IАЖЕНЬ І ПУБАІКАЦІЙ}

Теоретичним підгрунтям статті слугували наукові праці, в яких досліджуються різноманітні аспекти особливості державного регулювання реалізації публічноприватного партнерства у будівництві Петленко Ю.В. і Рожко О.Д., Рогожина П.С. і Гойко А.Ф., Чистова С.М. Напрями реформування і розвитку державної політики реалізації публічно-приватного партнерства у бу- дівництві розглядалися в працях таких вчених: Поважного О.С., Герасимчука З.В. і Хвищуна Н.В., Смереки С.Б. Проблемні питання формування фрінансового забезпечення комунальних суб'єктів господарювання висвітлено в працях Чиж В., Забаштанського М.М., Чистова С.М. та інших.

\section{META АОС $А$ АЖЕНHЯ}

Метою проведеного в поданій статті дослідження $\epsilon$ виявлення особливості державного регулювання реалізації публічно-приватного партнерства у будівництві.

\section{ВИК ААА ОСНОВНОГО МАТЕРІААУ}

Вчені та фахівці виділяють специфрічні особливо сти ППП, що відрізняють даний спосіб співпраці від інших форм економічних відносин держави і приватного бізнеcy:

- тривалі, терміном від 10 до 20 років, а в ряді випадків - до 50 років дії контрактів про співпрацю;

- унікальність реалізованих проєктів, які створюються з урахуванням особливостей техніко-економічного обгрунтування, створення та функціонування об'єктів виробничої, транспортної та соціальної інфрраструктури;

- спільне фрінансування проєктів, що здійснюється за рахунок використання державних, муніципальних i приватних інвестицій в обсягах, встановлених договором про співпрацю;

- висновок кожного контракту з реалізацією конкурсних процедур, в яких переможцем оголошується фрірма, яка запропонувала найбільш ефективний варіант партнерських відносин, що забезпечує досягнення максимальної ефективності проєкту для всіх учасників, 3 урахуванням наявності у кожного з них специфрічних інтересів, пов'язаних з різними фракторами участі в проєкті;

- забезпечується такий розподіл відповідальності між партнерами, при якому держава бере на себе виконання таких функцій: 
- визначає цілі і кінцеві результати реалізації проєкту з позицій суспільних і загальнодержавних інтересів;

- встановлює натуральні, вартісні і тимчасові оріє нтири проєкту і показники його соціально-економічної, бюджетної і екологічної ефективності [1, с. 87].

Приватний партнер в таких проєктах бере участь у його співфінансуванні і забезпечує виконання поточної оперативної діяльності, пов'язаної з:

- розробкою техніко-економічного обгрунтування,

— обгрунтуванням бізнес-плану проєкту,

- проєктуванням,

- будівництвом,

- експлуатацією,

- проведенням ремонтно-профрілактичних робіт,

- управлінням,

- дотриманням трудового та природоохоронного законодавства,

- наданням сертифікованих, якісних послуг споживачам створюваної продукції і послуг.

У науковій літературі позначилися два підходи до розуміння терміна ППП. Відповідно до одного з них, ППП ототожнюється з формою непрямої приватизації державної власності; відповідно до іншого -партнерство фрормується на стику державного і приватного сектора економіки і дозволяє використовувати переваги кожного з них для надання населенню суспільних благ.

На думку П.С. Рогожин, А.Ф. Гойко, конструктивним змістом інституту ППП є те, що він $€$ повноцінною альтернативою приватизаційним програмам, дозволяючи повною мірою реалізувати потенціал підприємницької ініціативи, але при цьому зберігши контрольні функції в руках держави для соціально та економічно значущих секторів економіки [2, с. 135]. Такий підхід дозволяє стабілізувати взаємовідносини всередині різних верств сучасного українського суспільства, різною мірою брав участь у процесі приватизації української власності, в результаті якого виник істотний розрив у доходах різних груп населення.

Найбільш поширеними як у світовій, так і в українській практиці є такі форми ППП, як операторський контракт, оренда, концесія, контракт життєвого циклу. За оцінками експертів, три види концесійних угод сьогодні $\epsilon$ найбільш поширеними в інфраструктурних галузях світової економіки [3]:

- на діючі об'єкти виробничої, транспортної та соціальної інфраструктури;

- на створення нових об'єктів або модернізацію морально чи фізично застарілих;

- на передачу об'єктів державної власності в оперативне управління приватним компаніям.

У межах зазначених вище видів можливі різні поєднання прав і правочинів сторін угоди. Проєкти ППП фахівці ідентифікують наступним чином:

БЕП (будівництво - експлуатація / управління передача). Інфрраструктурний об'єкт створюється за участю власних і позикових коштів приватних інвесторів, які отримує право експлуатації об'єкта протягом терміну, необхідного для повної окупності вкладених у нього приватних інвестицій і отримання норми прибутку, що забезпечує конкурентоспроможність проєкту в по- рівнянні з альтернативними варіантами довгострокового інвестування. Після закінчення терміну концесії об'єкт передається власнику, який визначає варіанти його подальшого використання, в томучислі - варіант продовження концесії на наступний термін.

БВЕП (будівництво - володіння - експлуатація / управління - передача). За такою схемою здійснюються концесії в дорожньому господарстві, шляхом створення платних ділянок автодоріг на період, який повинен забезпечити рентабельність проєкту, яка в свою чергу залежить від інтенсивності руху потоку автотранспорту і тарифрів оплати проїзду для різних категорій автомобілів. В сучасних умовах в Україні в термін окупності проєктів становить від 10 до 20 років, а термін концесійної угоди - від 20 до 30 років [4, с. 89]. Ці параметри визначають ділянки автомобільних доріг, які, в залежності від прогнозованої інтенсивності руху та плати за проїзд для різних видів транспортних засобів, можуть переводитися в платний режим на умовах концесії або контракту життєвого циклу;

БПЕ (будівництво - передача - експлуатація / управління). За такою схемою здійснюються операторські контракти на утримання ділянок автомобільних доріг, реалізованих раніше в формі концесійної угоди. Перевагою таких контрактів $є$ зниження витрат і зростання якості обслуговування для спеціалізованих фірм, що мають досвід такого виду діяльності;

БВЕ (будівництво - володіння - експлуатація / управління). Такий варіанти ППП виникає у випадках експлуатації промислового об'єкта, який фактично є монопольним користувачем транспортних послуг, наприклад велике підприємство гірничорудної або вугільної промисловості, в цьому випадку термін реалізації угоди ув'язується з терміном експлуатації об'єкта [5, с. 110];

БЕОП (будівництво - експлуатація / управління обслуговування - передача). Такий механізм реалізується в проєктах житлово комунального господарства, при передачі з муніципального балансу приватним інвесторам об'єктів водопостачання, водовідведення, теплопостачання та інших видів комунальних послуг для населення [6, с. 96]. Проєкт може бути пролонгований при виконанні сторонами своїх зобов'язань за проєктом і відсутності великого числа нарікань з боку населення, що обслуговується;

ПБВЕП (проєктування - будівництво - володіння - експлуатація / управління - передача), коли приватний партнер бере зобов'язання не тільки з будівництва, але й з проєктування об'єкта.

Такі проєкти дозволяють оптимізувати витрати на стадії капітального будівництва і можуть застосовуватися для великих проєктів, що мають фіксований термін введення їх в експлуатацію, наприклад проведення Олімпіади або чемпіонату світу з футболу; ПБФЕ (проєктування - будівництво - фінансування - експлуатація / управління), що включає спеціальний механізм фінансової відповідальності приватного партнера при проєктуванні, будівництві та експлуатації об'єкта. Такі проєкти прийнято називати контрактами життєвого циклу, які, поряд з концесіями, знаходять широке застосування в транспортній інфраструктурі, і зокрема в дорожньому господарстві. В таких проєктах держава будує взаємини з приватним бізнесом за допомогою: 
- розробки стратегії і основоположних принципів регулювання відносин приватного бізнесу з громадськістю та публічною владою;

- фрормування інституційної та законодавчої середовища, що створює сприятливі умови для реалізації ППП - проєктів;

- ефективної організації та управління проєктом на основі адекватних фрорм, методів і механізмів оптимізації діяльності для всіх учасників партнерства [7, с. 49].

\section{ВИСНОВКИ}

Створенням об'єктів ППП від імені держави можуть здійснювати профрільні міністерства і відомства, в також спеціально створені для цих цілей агентства. До її завдань входить створення на платній основі автомобільних доріг або переклад діючих ділянок автомобільних доріг, для яких інтенсивність руху і плата за проїзд забезпечують окупність і рентабельність проєкту, що влаштовує приватних інвесторів. Востанній час у проєктах ППП перевага віддається КЖЦ - проєктам, оскільки в умовах кризи вони надають для інвесторів істотне зниження ризиків у порівнянні з концесією. Приватні інвестиції в дорожнє будівництво для проєктів, протягом найближчого десятиліття, передбачається довести до 4-5\% від величини ВВП, а співвідношення державного і приватного фрінансування в них наблизити до величини 35:65. Однак такі плани було розроблено ще до кризи 2014 року, тому в сучасних проєктах умови фрінансування переглядаються таким чином, щоб приватні інвестори мали можливість окупити інвестиції в термін до 15 років.

Література:

1. Петленко Ю.В., Рожко О.Д. Місцеві фрінанси. К.: Кондор, 2019. - 282 с.

2. Рогожин П.С., Гойко А.Ф. Економіка будівельних організацій. К.: Видавничий дім "Скарби", 2018. 448 с.

3. Чистов С.М. Державне регулювання економіки: навч. посіб. / С. М. Чистов, А.Є. Никифоров, Т.Ф. Куценко. URL: / / studentam.kiev.ua/content/view /636/76/

4. Поважний О.С., Дорофієнко В.В., Осипенко І.М. та ін. Наукові засади реформування і розвитку житловокомунального господарства: монографія. Черкаси: Брама-України, ЧДТУ, 2017. 331 с.

5. Герасимчук 3.В., Хвищун Н.В. Формування недержавного сектора житловокомунального господарства в регіоні: монограія. Луцьк: Надстир'я, 2017. 224 с

6. Смерека С.Б. Особливості антикризового управління в житлово-комунальному господарстві. Актуальні проблеми економіки. № 1 (91). 2016. С. 92-97.

7. Чиж В. Формування економічно обгрунтованих тарифрів на житловокомунальні послуги. Економіст. 2017. № 8. С. 49-51.

\section{References:}

1. Petlenko, Yu.V. and Rozhko, O.D. (2019), Mistsevi finansy [Local finances], Kondor, Kyiv, Ukraine.

2. Rohozhyn, P.S. and Hoiko, A.F. (2018), Ekonomika budivelnykh orhanizatsii [Economics of construction companies], Vydavnychyi dim "Skarby", Kyiv, Ukraine.
3. Chystov, S.M. Nykyforov, A.Ye. and Kutsenko, T.F. (2004), Derzhavne rehuliuvannia ekonomiky: navch. posib. [State regulation of the economy: textbook], KNEU, Kyiv, Ukraine.

4. Povazhnyi, O.S. Dorofiienko, V.V. Osypenko, I.M. and others (2017), Naukovi zasady reformuvannia i rozvytku zhytlovokomunalnoho hospodarstva: Monohrafiia [Scientific principles of reforming and development of housing and communal services: Monograph], BramaUkrainy, ChDTU, Cherkasy, Ukraine.

5. Herasymchuk, Z.V. and Khvyshchun, N.V. (2017), Formuvannia nederzhavnoho sektora zhytlovokomunalnoho hospodarstva $v$ rehioni: Monohraiia [Formation of the private sector of housing and communal services in the region: Monograph], Nadstyrya, Lutsk, Ukraine.

6. Smereka, S.B. (2016), "Features of anti-crisis management in housing and communal services", Aktualni problemy ekonomiky, vol. 1 (91), pp. 92-97.

7. Chyzh, V. (2017), "Formation of economically justified tariffs for housing and communal services", Ekonomist, vol. 8, pp. $49-51$.

Стаття надійшла до редакчї 05.10.2021 p.

\section{Науково-практичний жсрнал} «ЕКОНОМІКА ТА ДЕРЖАВА»

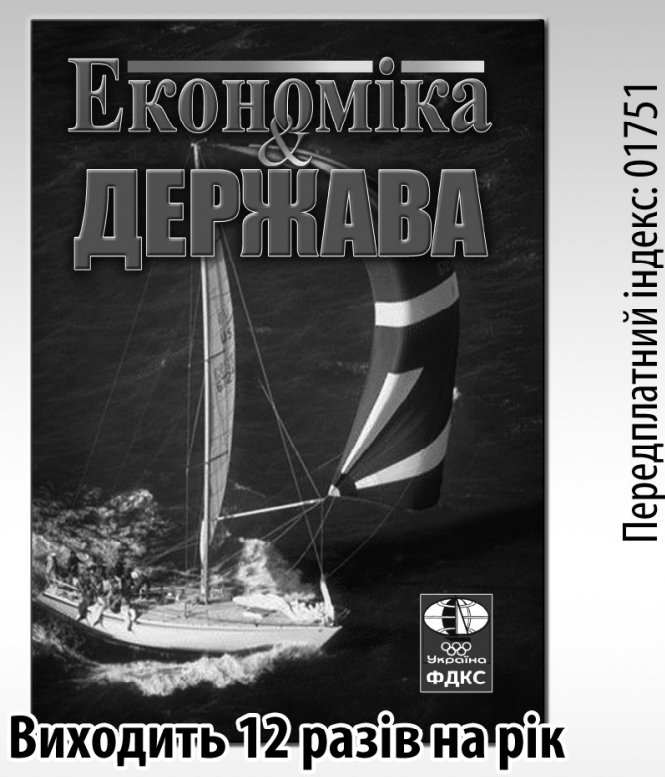
наукове фахове видання України 3 ПИТАНЬ ЕКОНОМІКИ

(Категорія «Б»)

Наказ Міністерства освіти і науки України від 28.12.2019 №1643

Спеціальності - 051, 071, 072, 073, 075, 076, 292.

www. economy.in.ua

e-mail: economy_2008@ukr.net

тел.: (044) 223-26-28

(044) 458-10-73 